\title{
Chalcophile element fertility of shoshonitic arc magmas: insights from Platinum-Group Element geochemistry at Vulcano Island (Italy)
}

\author{
SIMONE COSTA ${ }^{1,2}$, PAOLO FULIGNATI ${ }^{3}$, IAN H. \\ CAMPBELL $^{4}$, ANNA GIONCADA ${ }^{2}$, CARLOS IGNACIO \\ CARRASCO GODOY ${ }^{5}$ AND MARCO PISTOLESI ${ }^{2}$
}

${ }^{1}$ Università di Pisa

${ }^{2}$ University of Pisa

${ }^{3}$ Dipartimento di Scienze della Terra, University of Pisa

${ }^{4}$ Australian National University

${ }^{5}$ Research School of Earth Sciences, The Australian National University

Presenting Author: simone.costa@unifi.it

We report platinum-group-elements (PGE), Re and Au data for the shoshonitic suite (from basalt to rhyolite) of Vulcano (Aeolian Islands, Italy). These are the first PGE data obtained on Aeolian arc magmas. The aim was to investigate, through PGE geochemistry, the chalcophile element behavior during evolution in an active arc volcano with possible implications for chalcophile element fertility of arc magmas. The results show that the most primitive Vulcano magma was saturated with a Ptrich alloy, and is characterized by fractionation of IPGE relative to the PPGE, which is a typical feature of arc-type mafic magmas. A negative $\mathrm{Au}$ anomaly shown by primitive and intermediate magmas suggests the partitioning of $\mathrm{Au}$ in an early exsolved sulfur- (and moderately $\mathrm{Cl}$ ) rich gas phase, which, without affecting $\mathrm{Cu}$, may transport $\mathrm{Au}$ to higher levels, enhancing the mineralizing potential of the magmatic system. The Pd content of Vulcano magmas is high. Pd behavior, coupled with chalcophile elements fractionation modeling, reveals that the magmatic system reached sulfide saturation at about 4 wt.\% $\mathrm{MgO}$, although the very low sulfide fraction is not detectable in the samples. The very low proportion of immiscible sulfide precipitation was enough to cause a slight depletion in $\mathrm{Pd}$ but not enough to have a significant influence on $\mathrm{Au}$ and $\mathrm{Cu}$. The fraction of sulfide separated increases to $0.2 \mathrm{wt} \%$ at about 2 wt.\% $\mathrm{MgO}$, where enhanced sulfide saturation occurred. Modeling of the chalcophile elements shows that sulfide saturation occurred sufficiently before late volatile exsolution, expected at the rhyolite stage, to produce a significant chalcophile metal depletion in the silicate melts from which a hydrosaline aqueous fluid phase separates. As a consequence, a fluid exsolved from the rhyolite melt is unlikely to contain enough $\mathrm{Cu}$ and $\mathrm{Au}$ to form an ore deposit. However, the evidence of an early exsolved S-rich fluid, which depleted the magma in Au, suggests that arc magmatic systems like Vulcano may have the potential to evolve toward Au mineralized systems. 